Al Mubarokah E Prasetya, 2020

Volume 5 Issue 3, pp. 906-915

Date of Publication: 26 th February 2020

DOI- https://doi.org/10.20319/pijss.2020.53.906915

This paper can be cited as: Al Mubarokah, L. E Prasetya, W., (2020). The Role of Family and School in English Language Learner Identity Construction: An Indonesian Case. PEOPLE: International Journal of Social Sciences, 5(3), 906-915.

This work is licensed under the Creative Commons Attribution-Non Commercial 4.0 International License. To view a copy of this license, visit http://creativecommons.org/licenses/by-nc/4.0/ or send a letter to Creative Commons, PO Box 1866, Mountain View, CA 94042, USA.

\title{
THE ROLE OF FAMILY AND SCHOOL IN ENGLISH LANGUAGE LEARNER IDENTITY CONSTRUCTION: AN INDONESIAN CASE
}

\author{
Laelah Al Mubarokah \\ English Language Education, Universitas Islam Indonesia, Yogyakarta, Indonesia \\ laela1301@gmail.com \\ Willy Prasetya \\ English Language Education, Universitas Islam Indonesia, Yogyakarta, Indonesia \\ willy.prasetya@uii.ac.id
}

\begin{abstract}
In the process of learning English, a learner constantly reshapes his/her identity as he/she goes through different learning experiences. A particular experience may be added as a new part to a learner's perceived identity or replace another part of it. The present study examined how an Indonesian reconstructed her identity as an English language learner (ELL) as she went through various learning experiences since childhood to university level in two different countries. In-depth interview was conducted to collect the participant's account on her experiences, followed by several online correspondences within two months after the interview was conducted. The results of this study indicated that parental support and school policy and environment played an important role in reshaping the participant's identity. Her identity construction was then explained using Gee's (2000) four perspectives of identity. This study extends the research on learner identity particularly in Indonesian context or any other contexts with nearly similar characteristics.
\end{abstract}

\section{Keywords}

English Language Learning, Learner Identity, EFL, Parental Support, School Policy 


\section{Introduction}

English has become the most preferred foreign language to be studied in Indonesia, particularly, due to its status as an international language. Hadisantosa (2010) highlighted the perception among Indonesians that English is the best way to be able to participate directly in the global engagement and implying the importance of learning English. In elementary level, although English is not a compulsory subject, many elementary schools offer English classes because students tend to prefer schools with English subject (Kirkpatrick, 2012). As for high school level, English is one of the subjects of the national examination. English also has a special place in higher education. Most Indonesian universities require their students to attain a certain standard level of TOEFL in order to graduate and even several universities make English as a medium of instruction.

In the process of learning English, a learner constantly reshapes his/her identity as he/she goes through different learning experiences. Norton (2016) also emphasized that identity is constructed continuously as an individual experiences things from time to time and in one place to another. Thus, a particular experience may be added as a new part to a learner's perceived identity or replace another part of it.

Regarding the instability and uniqueness of individual identity construction process that quantitative research cannot accommodate, Hajar (2017) urged the need for more qualitative research on identity. Thus, the present study examined how an English language learner (ELL) reconstructed her identity as she went through various learning experiences since childhood to university level. Indepth interview was conducted to collect the participant's account on her experiences, which were then analyzed using Gee's (2000) four perspectives of identity. The Gee's perspectives of the study were as follows.

- Nature identity

- Institution Identity

- Affinity Identity

- Discourse Identity

This study extends the research on learner identity particularly in Indonesian context or any other contexts with similar characteristics of learners. 


\section{Literature Review}

Each person constructs his/her identity in a way different from the others. Gee (2000) highlighted that identity "can change from moment to moment in the interaction, can change from context to context, and, of course, can be ambiguous or unstable” (p. 99). In addition, Norton (2016) defined identity as "the way a person understands his or her relationship to the world, how that relationship is structured across time and space, and how the person understands possibilities for the future (p. 476)." Particularly, in the context of English language learning, Morgan (1996) emphasized that identity "is a guide with which ESL students negotiate their place in a new social order and ... challenge it through the meaning-making activities they participate in" (p. 419). To sum up, identity influences how a learner perceives him/herself within a particular context but at the same time is influenced by what the learner experiences.

Gee (2000) asserted that identity is constructed in four ways: nature identity, institution identity, discourse identity, and affinity identity. Nature identity is related to any traits that come since a person was born or from any uncontrollable natural occurrence, such as physical growth, aging, disability, etc. Institution identity comes from any entities with authority to assign particular status, such as being a student, a teacher, a librarian, etc. Discourse identity is derived from how other people logically perceive and talk about a person's characteristic. Finally, affinity identity comes from the involvement in a group with a particular set of practices and values.

Previous studies on learner identity have revealed the role of various aspects in identity formation. Ishiki (2013) examined how a Filipino American negotiated his identity. Ishiki revealed that the participant pretended to be a struggling English learner to fit in with his class where he was placed with other struggling learners despite his good English proficiency. In addition, the participant was excluded from Tagalog-speaking Filipino American classmates due to his lack of fluency in language while being accepted in a Japanese-speaking community at his school for his struggle to fit in through learning the language. Hajar (2017) reported the effects of teachers, family members, and peers as mediating social agents for two Syrian learners who studied in the UK in reconstructing their learner identities. He further indicated change in learning motivations and beliefs after going through different teacher practices with different parental support for each participant. In Indonesian setting, Wirza (2018) revealed the role of teachers in reshaping the identities of two Indonesian learners. In her study, one participant's identity was challenged when he encountered difficulties in communicating with teachers from Canada and Australia, while another participant who was initially resistant to English became interested in the language thanks to her English private teacher. Regarding the 
abovementioned studies, it is important to note that identity can be constructed by the influence of families, social services, workplaces, and schools (Norton, 1997). Norton \& Toohey (2001) further added that community and affiliation or group has a big impact on language learners.

\section{The Participant}

The participant of this study was Putri (pseudonym). Her mother as was an English lecturer and her father had a bachelor degree in English Literature. She lived two years in Adelaide, Australia, because her mother continued her study there for a master's degree. She completed first and second grades of elementary school in Australia. After going back to her hometown in Palu, Indonesia, Putri studied in a state elementary school. Then, she continued her study in a private Islamic school both for junior and senior high levels. The school required all students to communicate using English on several days in a week and punishment would be given to those who spoke any other languages. After graduating from high school, she moved to Yogyakarta to pursue a bachelor degree in management in an international program at a private university. One of the requirements for enrolling in that program was having at least a TOEFL score of 450 , and her score was 530. She was required to use only English in all classes that she attended, because the program implemented English as a medium of instruction (EMI).

\section{Data Collection and Analysis}

A case study of this study was implemented to focus on specific issue or feature and this research design was chosen to understands the complex real-life experiences, because there many sources of evidence were used. Case study become useful, in which researcher needs to understand some particular problem or situation in great-depth and can identfy cases rich in information (Noor, 2008). An in-depth two-hours interview was conducted to collect the participant's account on her learning experiences.

The interview was set up in a friendly and comfortable situation at the participant's university, so, that she could freely recount her experiences and express her feelings on any particular events during her learning process. The interview was semi-structured, meaning that only several questions were prepared to guide the interview process that eventually led to more questions about more details of the participant's experiences. Several follow-up online correspondences were also conducted within the period of two months after the interview was conducted. The data were then analyzed using Gee's (2000) four perspectives of identity to outline key points in the participant's learning experiences. 


\section{Findings}

Putri's family had been familiar with English, because her mother was an English lecturer and her father earned a bachelor degree in English literature. Putri started learning the language when she was in the first grade of elementary school. At that time, her family had to move to Australia, because her mother got a scholarship to continue her master's degree. In the first two months in Australia, Putri had difficulties in terms of communication, because she had not been able to speak English. Hence, she tended to be quiet and did not interact with anyone. Thus, her brother gave her a sign saying, "I don't understand what you are saying" to show that she could not respond to anyone who tried to talk to her. One day, her parents were invited to meet her teacher and discuss Putri's language problem. Because of this issue, her parents obliged Putri and her siblings to use English at home. It took 3 months to make her able and confident to speak English although she had not been fluent. Putri recounted:

When I came to Australia, my knowledge of English was only counting one to ten, but after I could adapt with the language, I could fight and debate with my brother and sister using English and my father said that it was okay to fight as long as we used English.

When Putri returned to Indonesia, English became the first language in her family. Her parents were worried that she and her siblings would lose their English after leaving Australia. Therefore, her parents would not respond to anything that she or her siblings said using Indonesian language. Her mother would occasionally said, 'I don't understand what you are saying' or 'English please' severely in to remind her children to speak English. Putri recalled:

The English language has become our primary language at home and my parents also said that English is really really important and they want me to be able to exceed their abilities both in language or career education.

When she continued to the third grade of elementary school in Indonesia, Putri had to adapt with the language again, because it was difficult for her to speak Indonesian language. Her interaction with her friends was limited, but many of her friends approached her especially when there were English classes at school because her English skills were above the average of Indonesian students. After finishing elementary school, Putri continued to a private Islamic high school of her choice. The school required her and all other students to speak English on several particular days. She participated in several competitions of English speech, storytelling, and scientific paper. Her school provided her with a tutor for each competition that she joined in. In the second grade of senior high school, she had 
the opportunity to go to Japan to attend an international youth forum as her school representative. One year after that, she went to the United States to join an international science and engineering fair.

Upon returning from the United States, Putri missed the opportunity to enroll in any state universities through the national selection examination. Therefore, she decided to pursue a bachelor degree in management in a private Islamic university in Yogyakarta, Indonesia. She enrolled in the international program at the university, in which English became the medium of instruction for all subjects. At the university, Putri's classmates relied on her in terms of English. When a professor asked a question to the class, her classmates always asked her to be the first to answer because her English proficiency was above the average Indonesian people. In short, her classmates looked up to her. Besides attending classes, she also joined a student forum specifically for those enrolled in the international program.

Being a university student, Putri believed that she had the capability to deal with the demand in the international program, but she found out that she still had a lot of things to learn.. Putri reported:

In the international program, there was a bridging program that really helped me because it bridged the gap between high school and college so that the students were ready for studying in the international program, particularly in using English. The course also covered academic writing and speaking, and I realized that my academic English skills was still low because of limited vocabulary. It was probably because I always used informal language.

During the first year at the university, she could improve her academic vocabulary thanks to her curiosity in English and her willingness to learn.

\section{Discussion}

The findings indicated that there were two factors that played an important role in Putri's identity construction as an ELL learner, namely parents and school. Several previous studies have also indicated that the role of school (Ali, Hamid \& Moni, 2011; Tsui \& Ngo, 2016; Pritasari, Reinaldo \& Watson, 2018) and parental support (Bartram, 2006; Wei, 2011; Gao, 2012; Bruin, 2017) were vital in English language learning process. The role of parents and school in this study were discussed using Gee's (2000) four perspectives of identity. However, as Gee (2000) pointed out, these perspectives correlate to each other and should not be treated individually. Thus, there might be several intersections among these perspectives.

At the beginning of her time in Australia, Putri's nature identity was reflected in her selfidentification as a silent student. Her teacher, the representative of her school as an institution, also 
noticed her lack of interaction with friends, and she was identified as a struggling student in terms of English communication skills. When her teacher called her parents to discuss her lack of English, they agreed that Putri needed help with her English; this kind of agreement on Putri's low English proficiency represented discourse identity. Thus, her parents required her and her siblings to use only English at home to improve her English. With particular rules and punishment regarding English, putri's family became the basis for her affinity identity.

Upon returning from Australia, Putri did not stop using English both at home and school. Her friends identified herself as a student who was good at English, so, she became more confident with her English. Her parents' expectations on her English proficiency also motivated her to get involved in English-related competitions and events. Besides her parents, her learning experiences at school also contributed to her identity formation. In addition, her high school policy of using English on certain days as well as support for her participation in English competitions and international involvement improved her proficiency in English. In university, she was taught using English as a medium of instruction (EMI) for all courses. She felt that there was improvement particularly in her academic English skills. As Andrade (2009) pointed out, EMI could improve learners' English skills so they could compete with at least friends in the classroom. Tsui and Ngo (2016) also revealed that students recognized the real impact of EMI in improving fluency in English, which might later help them get better career opportunities.

\section{Conclusion}

This study examined how an English language learner reshaped her identity as she went through various learning experiences since elementary school to university level in two different countries. The participant's identity was viewed using Gee's (2000) four perspectives of identity. The results showed that the participant's nature identity changed from a passive student due to lack of English proficiency into the one who was fluent in communicating using English. In terms of institution identity, the participant was initially considered a struggling student until she learned English and became acknowledged by her school for participating in competitions and international events. The participant's discourse identity was greatly influenced by how her friends recognized her English proficiency. They considered her an excellent student who could help them with English. As for affinity identity, the participant's family became the first place, in which she followed the practice of using English daily and being warned or scolded for using other languages. Then, she took part in 
international involvement activities and a university student forum and learned various styles of interaction and other social activities.

This study extends the research on learner identity, particularly, in Indonesian context or other contexts with nearly similar characteristics, such as southeast Asian countries with English as a foreign language. As there is a significant increase in international mobility in the region, identity construction among individual English language learners becomes more dynamic and unique. Thus, more qualitative research on the topic is required to gain more insight into how learners cope with challenges from various learning experiences. The study has contributed to a fuller understanding of how an Indonesian reconstructed her identity as an English language learner (ELL) as she went through various learning experiences since childhood to university level in two different countries. Given the importance of identity in the learners'experiences as EFL learners and users especially since empirical research on learner identity is still in its infancy, future research is needed to more investigation of learner identity in diverse contexts because it is useful for language teachers to inform their learning and curriculum practices. But, on thing that needs to watch out for is the result of this study cannot be linked with EFL or ESL learners because of different contexts. And the different family background is the limitation determinant for this scale of research.

\section{References}

Ali, N. L., M. Hamid, M. O., \& Moni, K. (2011). English in primary education in Malaysia: policies, outcomes and stakeholders' lived experiences. Current Issues in Language Planning, 12(2), 147-166. Retrieved from https://doi.org/10.1080/14664208.2011.584371

Andrade, M. S. (2009). The effects of English language proficiency on adjustment to university. International Multilingual Research Journal, 3(1), 16-34. Retrieved from doi: https://doi.org/10.1080/19313150802668249

Bartram, B. (2006). An examination of perceptions of parental influence on attitudes to language learning. Educational Research, 48(2), 211-221. Retrieved from https://doi.org/10.1080/00131880600732298

Bruin, M. (2017). Parental involvement in children's learning: The case of cochlear implantationparents as educators?. Scandinavian Journal of Educational Research, 62(4), 601-616. Retrieved from https://doi.org/10.1080/00313831.2016.1258728 
Gao, X. (2012). Parental strategies in supporting chinese children's learning of English vocabulary.

Research Papers in Education, 27(5), 581-595. Retrieved from https://doi.org/10.1080/02671522.2011.602102

Gee, J. P. (2000). Chapter 3: Identity as an analytic lens for research in education. Review of Research in Education, 25(1), 99-125. Retrieved from https://doi.org/10.3102/0091732X025001099

Hadisantosa, N., Huong, T. T. T., Johnstone, R., Keyuravong, S., \& Lee, W. (2010). Learning through English: policies, challenges and prospects insight from East Asia. Malaysia: British Council

Hajar, A. (2017). Identity, investment and language learning strategies of two Syrian students in Syria and Britain. Language, Culture and Curriculum,30(3), 250-264. Retrieved from https://doi.org/10.1080/07908318.2017.1317266

Ishiki, N. (2013). Negotiation of identity: (Re) construction and (Re) positioning of self through language learning. Indonesian Journal of Applied Linguistics, 3(1), 39-53. Retrieved from https://doi.org/10.17509/ijal.v3i1.189

Kirkpatrick, A. (2012). English in ASEAN: implications for regional multilingualism. Journal of Multilingual and Multicultural Development, 33(4), 331-344. Retrieved from https://doi.org/10.1080/01434632.2012.661433

Morgan, B. (1996). Promoting and assessing critical language awareness. TESOL Journal, 5(2), 1014.

Noor, K. B. M. (2008). Case study: A strategic research methodology. American journal of applied sciences, 5(11), 1602-1604. https://doi.org/10.3844/ajassp.2008.1602.1604

Norton, B. (1997). Language, identity, and the ownership of English. TESOL Quarterly, 31(3), 409429. Retrieved from https://doi.org/10.2307/3587831

Norton, B. (2016). Identity and language learning: back to the future. TESOL Quarterly, 50(2), 475479. Retrieved from https://doi.org/10.1002/tesq.293

Norton, B., \& Toohey, K. (2001). Changing perspectives on good language learners. TESOL Quarterly, 35(2), 307-322. Retrieved from https://doi.org/10.2307/3587650

Pritasari, A., Reinaldo, H., \& Watson, C. W., (2018). English-medium instruction in Asian business schools: a case study. Journal of Multilingual and Multicultural Development, 40(1), 1-13. Retrieved from https://doi.org/10.1080/01434632.2018.1458855

Tsui, A. P., \& Ngo, H., (2016). Students' perceptions of English-medium instruction in a Hong Kong university. Asian Englishes, 19(1),57-78. Retrieved from https://doi.org/10.1080/13488678.2016.1230484 
Wei, R. (2011). Parental support for Chinese-English bilingual education: a survey of parents of primary and secondary students in Shanghai. Journal of Multilingual and Multicultural Development, 32(5), 481-496. Retrieved from https://doi.org/10.1080/01434632.2011.592588

Wirza, Y. (2018). A narrative case study of Indonesian EFL learners' identities. Indonesian Journal of Applied Linguistics, 8(2), 473-481. Retrieved from https://doi.org/10.17509/ijal.v8i2.13313 